\title{
An Examination of Attitudes towards Cheating in Exams by Physical Education and Sports High School Students ${ }^{\mathrm{i}}$
}

\author{
Numan Bahadır Kayışoğlü ${ }^{1, *}$, Cenk Temel $^{2}$ \\ ${ }^{1}$ Hasan Doğan Physical Education and Sports High School, Karabük University, Turkey \\ ${ }^{2}$ Physical Education and Sports High School, İnönü University, Turkey
}

Copyright $\bigcirc 2017$ by authors, all rights reserved. Authors agree that this article remains permanently open access under the terms of the Creative Commons Attribution License 4.0 International License

\begin{abstract}
The purpose of this study is to determine the attitudes of students from the Hasan Doğan School of Physical Education and Sports towards cheating in exams and to investigate changes in these attitudes in terms of several variables. The survey method was used in the study. The study was conducted during the 2014-2015 Academic year at the Karabük University Hasan Doğan High School of Physical Education and Sports. The Study Group consisted of 178 student teachers from the Physical Education and Sports Department and 159 students from the Sports Management Department. In total, 337 students were selected, using the random sampling method. The Attitude Scale on Cheating in Exams (ASCE), developed by Semerci (2003), was used to collect the data. The scale consisted of one dimension and 67 items, 37 of which were positive and 30 of which were negative statements. The study data were analyzed using the SPSS Package Program. The t-test and One-Way Variance Analysis (ANOVA) were used to analysis the data. The Cronbach's Alpha reliability level of the scale used in the study was calculated to be .89 . By the end of the study, it was established that the students from the Physical Education and Sports High School had above average attitudes and that attitudes on cheating in exams did not differ according to gender, department, type of high school attended, and YGS points; however, it was also determined that the students' attitudes towards cheating in exams differed according to year level.
\end{abstract}

Keywords Cheating Behavior, Teacher Training, Physical Education Teacher Candidates

\section{Introduction}

The cheating behavior of students during exams is one of the biggest problems for educators and has long been a topic of interest for researchers. Cheating in exams refers to attempts by examinees to answer exam questions using pre-prepared materials O'Rourke et al. [1]. It can be achieved with cheat sheets (small pieces of paper), plagiarize the answers of other students, copying others' homework or letting other students copy theirs [2]. The view that society is an objective and education is an indispensable means to reach this objective was perfectly expressed by Aslan [3] with the rationale that cheating behaviors are reinforced and they continue after completing school in daily lives, which negatively affect society.

According to Balzer [4], education is closely interrelated with the whole social system in every industrial society. Whitley et al. [5], report that students, who cheat at high school, continue these behaviors at university and eventually these behaviors are emulated following school, as dishonesty in working life. Other empirical studies confirming these findings report that intended cheating behaviors at high school result in cheating and negative behaviors at graduate and professional schools, Baldwin et al. [6]; unethical behaviors in working life, Harding et al. [7]; shoplifting Beck et al. [8] and cheating on income tax returns Fass [9].

\subsection{Consequences of Cheating Behaviors}

In terms of corruption, in the individual or society, these important consequences of cheating behaviors prevent students from learning meaningfully and experiencing the true sense of success, on one hand. On the other hand, these cause students to have internal conflicts and a sense of guilt [10]. Additionally, cheating behaviors complicate the assessment of the true level of achievement of the class and results in uncertainty. Some of the primary effects of cheating in education are reported to be: 1 - Decreasing the validity and the reliability of the exams and assessments, 2Preventing the detection of the extent of the program from attaining the objectives and the deficiencies, and 3-Preventing students' learning [11, 12, 13, 14].

Some educators believe that students can also learn as they attempt to prepare cheat sheets; however, when this view is considered from a moral perspective, this kind of behavior has more cons than pros. Any achievement accomplished in this way is actually unjust to others and this kind of thinking 
is nothing but giving credit to fraud. Moreover, the sense of guilt resulting from cheating can have a negative effect on mental health [13]. From the perspective of higher education institutions, it is reported that cheating behaviors at universities, which are respected by society, may decrease the trust society has in universities $[15,5]$.

\subsection{Reasons of Cheating Behaviors}

The main reasons for cheating are the rote learning based education system and the uniform assessment methods. Assessment tools used in education should not require students to collect information and remember, memorize and present it, but should be designed in a way that requires students to analyze and interpret the collected information. According to Wajda-Johnston et al. [16] and Çetin [10], replacing the monotype assessment with one examination during and after the semester with different assessment methods covering different learning styles can decrease cheating behaviors [17]. At this point, Passow et al. [18], emphasize that measuring cheating behaviors without taking the differences in assessment styles into account would be a mistake.

In addition to these, reasons such as the fear of failure, pressure to get good grades, desire to avoid failure, assessment criteria being perceived as unfair, the lack of deterrent sanctions against cheating, cheating being easier and less labor-intensive, and exams having a significant influence on the students' future, are among the contributory factors that lead students to cheat [19].

\subsection{Prevalence of Cheating Behaviors}

Many previous studies conducted at various universities have revealed that cheating or academic fraud is commonplace $[20,21,22,18,15]$. A previous study conducted by Bowers [20] in 1963 at nine universities was re-conducted in 1993 by McCabe [21] and the percentages of students who reported that they cheated were comparatively similar (82\% in 1963 and 84\% in 1993). However, this study also reported significant increases in different forms of cheating, such as cheating from another student in the exam, from $26 \%$ to $52 \%$, and helping each other with work assigned by professors from $11 \%$ to $49 \%$ [21]. Cheating behaviors can be observed at any level of education, but their frequencies at higher education were reported as two-thirds by Stern et al. [23], $71 \%$ by Mert [24], and $80 \%$ by Robinson et al. [25], and McCabe et al. [26] stated that if the necessary measures were not taken, the situation would get worse.

Considering the prevalence of cheating and the way it affects educational quality and society, its prevention is vital and investigating cheating behavior among sports management and physical education teaching department students, who should be role models throughout their teaching lives, gain importance for the present research. In accordance with this, the purpose of the present research is to define the levels of attitudes towards cheating in the exams in terms of specific variables, such as department, year, gender, the type of high school attended and the score from the transition to higher education examination (YGS) among school of physical education and sport students.

\section{Method and Materials}

The method used in the current study is field research, the purpose of which is to investigate incidents and phenomena in their natural conditions, and the screening model is employed for this method. The purpose of screening is to describe an existing case. An attempt is made to describe the incident, individual, or object, as the subject of the research, in its own environment. No effort is made to change or affect these by any means. The point is to observe and define what is of concern [27]. The present research was conducted at Karabük University Hasan Doğan School of Physical Education and Sport in 2014-2015 academic year, and the work group comprised 178 Physical Education and Sport Teaching Department, and 159 Sport Management Department, a total of 337 students selected randomly from the entire student body of these two departments. Data related to work group are presented in Table 1.

In order to collect data for the present research, a personal information form and the Attitudes Towards Cheating scale, developed by Semerci [28], were employed. The scale is scored on a 5-point Likert-type scale, ranging from (1) Never, (5) Always and consists of 67 items, 30 of which are reverse scored. The alpha reliability coefficient of the scale was reported as .96 , and was calculated as .89 in the present research.

Data analyses were conducted using the SPSS software package. While entering the participants' responses in the program, positive items were coded as (1) Completely Disagree, (2) Mostly Disagree, (3) Partially Agree, (4) Mostly Agree and (5) Completely Agree; while the negative items were reversely coded. For data analyses, frequency, percentage, arithmetic average, standard deviation were used and as the data were not normally distributed, Mann-Whitney U and Kruskal-Wallis tests were utilized. For statistical calculations, the significance level was taken as .05 .

Findings related to Cronbach's Alpha reliability of the Attitudes Towards Cheating scale, which was used as the data collection tool, in order to define School Physical Education and Sport students' attitudes towards cheating in the exams, are presented in Table 1.

Table 1. Cronbach's Alpha Reliability Analyses for the Attitudes Towards Cheating Scale

\begin{tabular}{|c|c|c|}
\hline & N & Cronbach's Alpha \\
\hline Scale for Attitudes Towards Cheating & 67 & .895 \\
\hline
\end{tabular}

As presented in Table1, Cronbach's Alpha reliability coefficient of the 67-item Attitudes Towards Cheating scale 
was calculated as .895 , according to the reliability analyses. The reliability coefficient, being higher than .70 for a psychological test, is accepted as sufficient for reliability [29]. In accordance with this information, the reliability coefficient calculated for the scale indicates that the scores obtained from the scale are highly reliable. Data related to the demographic information of the 337 students from the School of Physical Education and Sport, who participated in the present research, are presented in Table 1.

Table 2. Frequency and Percentage Distributions for the Demographic Features of Participants

\begin{tabular}{|c|c|c|c|}
\hline Variables & Categories & $f$ & $\%$ \\
\hline \multirow{2}{*}{ Gender } & Male & 241 & 71.5 \\
\hline & Female & 96 & 28.5 \\
\hline \multirow{4}{*}{ Type of High School } & General & 159 & 47.2 \\
\hline & Anatolian HS & 82 & 24.3 \\
\hline & Vocational HS & 68 & 20.2 \\
\hline & Sport HS & 28 & 8.3 \\
\hline \multirow{4}{*}{ YGS score } & $181-230$ & 39 & 11.6 \\
\hline & $231-280$ & 88 & 26.1 \\
\hline & $281-330$ & 173 & 51.3 \\
\hline & 331 and over & 37 & 11.0 \\
\hline \multirow{2}{*}{ Department } & Teaching & 178 & 52.8 \\
\hline & Management & 159 & 47.2 \\
\hline \multirow{4}{*}{ Year } & First Year & 187 & 55.5 \\
\hline & Second Year & 70 & 20.8 \\
\hline & Third Year & 40 & 11.9 \\
\hline & Fourth Year & 40 & 11.9 \\
\hline Total & & 337 & 100 \\
\hline
\end{tabular}

Data related to the demographic features of the 337 students, who participated in the present research, are presented in Table 1. Of the 337 students, 96 (28.5\%) were female and $241(71.5 \%)$ were male. The distribution of the types of high schools from which the participants graduated, is as follows: $159(47.2 \%)$ graduated from general high schools; 82 (24.3\%) from Anatolian high schools; 68 (20.2\%) from vocational high schools and $28(8.3 \%)$ graduated from sport high schools. As for the distribution of the YGS scores (transition to higher education examination), $39(11.6 \%)$ of the students acquired 181-230 points; 88 (26.1\%) gained 231-280 points; 173 (51.3\%) gained 281-330 points and 37 $(11.0 \%)$ acquired 331 or more points. High schools in Turkey vary according to the quality of education and acceptance conditions. Anatolian high schools are schools that are mainly favored by students who have higher academic success in the placement examination. Students who have lower scores in the placement examination may favor general high schools, which have characteristics similar to Anatolian High Schools. Those who want to specialize in a particular proficiency may favor Vocational High Schools and Sports Schools. Universities in Turkey accept students through the transition according to the higher education examination (YGS). The minimum and maximum scores in YGS are 180 and 500, respectively. Therefore, a higher score for YGS can be interpreted as higher academic success.

As previously stated, 178 (52.8\%) of the students studied at the Physical Education and Teaching Department, while $159(47.2 \%)$ were Sports Management students. Of these students $187(55.5 \%)$ were freshmen $\left(1^{\text {st }}\right.$ year $), 70(20.8 \%)$ were sophomores ( $2^{\text {nd }}$ year $), 40(11.9 \%)$ were $3^{\text {rd }}$ year and 40 $(11.9 \%)$ were seniors $\left(4^{\text {th }}\right.$ year $)$.

\section{Findings}

This part presents findings obtained with the analyses of the data collected for the present research.

Table 3. Descriptive Statistics for the Students' Attitudes towards Cheating

\begin{tabular}{|c|c|c|c|c|c|}
\hline & $\mathrm{N}$ & Minimum & Maximum & $\bar{x}$ & $\mathrm{~S}$ \\
\hline $\begin{array}{c}\text { Attitudes } \\
\text { towards } \\
\text { Cheating }\end{array}$ & 337 & 85 & 329 & 199.19 & 34.30 \\
\hline
\end{tabular}

As can be seen in Table 3, the highest score students obtained from the Attitudes Towards Cheating scale was 329, while the lowest was 85 . The average score was 199.19 , and the calculated standard deviation value was 34.30 .

As can be seen from Table 4, there is no significant difference between the attitudes towards cheating scores of female students $(\bar{x}=202.45)$ and male students $(X=197.90)$ according to $\mathrm{t}_{(335)}=1.101, \mathrm{p}=.272>.05$.

Table 4. Independent Samples T-test Results for the Variation in Students' Attitudes towards Cheating by Gender

\begin{tabular}{|c|c|c|c|c|c|c|c|}
\hline & Gender & $\mathrm{N}$ & $\bar{x}$ & $\mathrm{~S}$ & $\mathrm{t}$ & $\mathrm{sd}$ & $\mathrm{p}$ \\
\hline \multirow{2}{*}{ Attitudes towards Cheating } & Male & 241 & 197.90 & 34.57 & \multirow{2}{*}{1.101} & \multirow{2}{*}{335} & \multirow{2}{*}{.272} \\
\cline { 2 - 6 } & Female & 96 & 202.45 & 33.58 & & & \\
\hline
\end{tabular}


Table 5. One-Way ANOVA Results for the Variation in Students' Attitudes towards Cheating by the Type of High School

\begin{tabular}{|c|c|c|c|c|c|c|c|c|c|}
\hline & High School Type & $\mathrm{N}$ & $\bar{x}$ & $\mathrm{~S}$ & $\begin{array}{l}\text { Sum of } \\
\text { Squares }\end{array}$ & $\begin{array}{l}\text { Mean } \\
\text { Square }\end{array}$ & $\begin{array}{c}\mathrm{F} \\
(333 / 3)\end{array}$ & $\mathrm{p}$ & $\begin{array}{l}\text { Post Hoc } \\
\text { (LSD) }\end{array}$ \\
\hline \multirow{4}{*}{$\begin{array}{l}\text { Attitudes towards } \\
\text { Cheating }\end{array}$} & General & 159 & 199.07 & 35.90 & \multirow{2}{*}{1090.02} & \multirow{2}{*}{363.34} & \multirow{4}{*}{.307} & \multirow{4}{*}{.820} & \multirow{4}{*}{---} \\
\hline & Anatolian & 82 & 200.05 & 36.13 & & & & & \\
\hline & Vocational & 68 & 200.75 & 31.50 & \multirow{2}{*}{394289.8} & \multirow{2}{*}{1184.05} & & & \\
\hline & Sport & 28 & 193.64 & 26.12 & & & & & \\
\hline
\end{tabular}

Table 6. One-Way ANOVA Results for the Variation in Students' Attitudes towards Cheating by YGS Scores

\begin{tabular}{|c|c|c|c|c|c|c|c|c|c|}
\hline & YGS Scores & $\mathrm{N}$ & $\bar{x}$ & S & $\begin{array}{l}\text { Sum of } \\
\text { Squares }\end{array}$ & $\begin{array}{l}\text { Mean } \\
\text { Square }\end{array}$ & $\begin{array}{c}F \\
(333 / 3)\end{array}$ & $\mathrm{p}$ & $\begin{array}{l}\text { Post Hoc } \\
\text { (LSD) }\end{array}$ \\
\hline \multirow{4}{*}{$\begin{array}{l}\text { Attitudes towards } \\
\text { Cheating }\end{array}$} & $181-230$ & 39 & 197.49 & 36.20 & \multirow{2}{*}{1231.38} & \multirow{2}{*}{410.46} & \multirow{4}{*}{.347} & \multirow{4}{*}{.792} & \multirow{4}{*}{---} \\
\hline & $231-280$ & 88 & 201.09 & 37.50 & & & & & \\
\hline & $281-330$ & 173 & 197.84 & 34.10 & \multirow{2}{*}{394148.4} & \multirow{2}{*}{1183.63} & & & \\
\hline & 331 and higher & 37 & 202.81 & 24.74 & & & & & \\
\hline
\end{tabular}

Table 7. Independent Samples T-test Results for the Variation in Students' Attitudes towards Cheating by Department

\begin{tabular}{|c|c|c|c|c|c|c|c|}
\hline & Department & $\mathrm{N}$ & $\bar{x}$ & S & $\mathrm{t}$ & sd & $\mathrm{p}$ \\
\hline \multirow{2}{*}{ Attitudes towards Cheating } & Teaching & 178 & 199.26 & 39.49 & \multirow{2}{*}{.040} & \multirow{2}{*}{335} & \multirow{2}{*}{.968} \\
\hline & Management & 159 & 199.12 & 27.48 & & & \\
\hline
\end{tabular}

Table 8. One-Way ANOVA Results for the Variation in Students' Attitudes towards Cheating by Class Years

\begin{tabular}{|c|c|c|c|c|c|c|c|c|c|}
\hline & Year & $\mathrm{N}$ & $\bar{x}$ & $\mathrm{~S}$ & $\begin{array}{l}\text { Sum of } \\
\text { Squares }\end{array}$ & $\begin{array}{l}\text { Mean } \\
\text { Square }\end{array}$ & $\begin{array}{c}F \\
(333 / 3)\end{array}$ & $\mathrm{p}$ & $\begin{array}{c}\text { Post Hoc } \\
\text { (LSD) }\end{array}$ \\
\hline \multirow{4}{*}{$\begin{array}{l}\text { Attitudes towards } \\
\text { Cheating }\end{array}$} & First & 187 & 195.13 & 32.16 & \multirow{2}{*}{11040.27} & \multirow{2}{*}{3680.09} & \multirow{4}{*}{3.189} & \multirow{4}{*}{$.024 *$} & \multirow{4}{*}{$\begin{array}{l}2>1 \\
4>1\end{array}$} \\
\hline & Second & 70 & 206.29 & 30.21 & & & & & \\
\hline & Third & 40 & 195.27 & 42.28 & \multirow{2}{*}{384339.5} & \multirow{2}{*}{1154.17} & & & \\
\hline & Fourth & 40 & 209.18 & 38.98 & & & & & \\
\hline
\end{tabular}

$*_{p}<0.05$ Categories: $1^{\text {st }}$ year $=1 ; 2^{\text {nd }}$ year $=2 ; 3^{\text {rd }}$ year $=3 ; 4^{\text {th }}$ year $=4$

As is shown in Table 5, there are no significant differences among the attitudes towards cheating scores of students who graduated from general high schools $(\bar{x}=199.07)$, Anatolian high schools $(\bar{x}=200.05)$, vocational high schools $(\bar{x}=200.75)$ and sport high schools $(\bar{x}=193.64)$ according to $\mathrm{f}_{(333 / 3)}=.307, \mathrm{p}=.820>.05$.

As can be seen in Table 6, there are no significant differences among the attitudes towards cheating scores of students who obtained 181-230 points from YGS $(\bar{x}=197.49), 231-280$ points $(\bar{x}=201.09), 281-330$ points $(\bar{x}=197.84)$ and 331 points or higher from YGS $(\bar{x}=202.81)$ according to $\mathrm{f}_{(333 / 3)}=.347, \mathrm{p}=.792>.05$.
As can be seen in Table 7, there are no significant differences among the attitudes towards cheating scores of teaching department students $(\bar{x}=199.26)$ and management department students $(\bar{x}=199.12)$ according to $\mathrm{t}_{(335)}=.040$, $\mathrm{p}=.968>.05$.

As is shown in Table 8, students' attitudes towards cheating scores of vary by class year $\left(\mathrm{f}_{(333 / 3)}=3.189\right.$, $\mathrm{p}=.024<.05)$. The source of this variation is the significant differences between scores of $4^{\text {th }}$ year students $(\bar{x}=209.18)$, $2^{\text {nd }}$ year students $(\bar{x}=206.29)$ and $1^{\text {st }}$ year students $(\bar{x}=195.13)$. 


\section{Discussion}

According to the findings of the present research, which was conducted to identify attitudes towards cheating in exams taken by students at a School of Physical Education, included some variables. These included department, class year, gender, the kind of high school from which they graduated and their scores from the transition to higher education examination (YGS), school of physical education and sport students attitudes towards cheating in the exams level average is $\bar{x}=199.19$. Considering the calculated average, students' attitudes towards cheating in the exams levels were above average.

While the average attitude level score from the scale was 167.5 , the average score of the students who participated in the present research, was 199.19, which indicates that students present an above average attitude towards cheating. In a previous study with a similar sample, Ünlü and Eroğlu [30] reported that pre-service physical education teachers' level of attitudes towards cheating was moderate. However, according to the findings of previous research, which studied the cheating rates at higher education, the rate is around $70 \%$ to $80 \%$ Stern and Havlicek [23], Mert [24], Robinson et al. [25], McCabe [26], Bozdoğan and Öztürk [31], which is in accordance with the findings of the present research. According to the findings of the present research, there are no significant differences between the attitudes towards cheating scores of female students $(\bar{x}=202.45)$ and male students $\quad(\bar{x}=197.90) \quad\left(\mathrm{t}_{(335)}=1.101, \mathrm{p}=.272>.05\right)$. Accordingly, the students' attitudes towards cheating do not vary by gender. Similarly, many previous studies have also reported that students' cheating behaviors and attitudes do not vary by gender [32, 30, 33, 34, 35, 36].

Conversely, there are some studies reporting that the levels of attitudes towards cheating of male students were higher than those of female students [37, 38, 39, 40, 41, 42]. Students' attitudes towards cheating scores do not vary according to the kind of high school from which they graduated. Accordingly, the research suggests that their high school programs do not have a significant effect on the attitudes of university students towards cheating. Another finding of the present research is that, students' attitudes towards cheating do not vary according to their YGS scores, which can be an indicator of academic achievement. In other words, academic achievement levels do not have a significant effect on cheating attitudes. Similarly, Ünlü and Eroğlu [30], Ellenburg [43], DeVries and Ajzen [44] reported that academic achievement levels do not have a significant effect on attitudes towards cheating. Nevertheless, previous studies have reported that attitudes towards cheating decrease with higher levels of academic achievement [35, 45].

The findings obtained in the present research also indicated that students' scores regarding attitudes towards cheating do not vary significantly by the department in which they studied. On the other hand, another study that considered cheating in terms of the fields of education at university reported that science students were more prone to cheating than arts students [46]. Finally, according to the findings relating to students' attitudes towards cheating, in terms of class year, there are significant differences among students in different years $\left(\mathrm{f}_{(333 / 3)}=3.189, \mathrm{p}=, 024<.05\right)$. The source of this difference is that the scores of $4^{\text {th }}$ year students $(\bar{x}=209.18)$ and $2^{\text {nd }}$ year students $(\bar{x}=206.29)$ are significantly different from the scores of $1^{\text {st }}$ year students ( $\bar{x}=195.13$ ). Accordingly, students' attitudes towards cheating vary by their class years, and $4^{\text {th }}$ and $2^{\text {nd }}$ year students are more prone to cheating, particularly with regard to $1^{\text {st }}$ year students. It is thought that age, together with more experience of school, could increase attitudes towards cheating.

\section{Conclusions}

As has previously been reported in many different studies, when all these findings are taken into consideration it is noteworthy that attitudes towards cheating by students attending schools of physical education and sports, who are expected to exhibit ethical behavior with their athletic identities, are above average when compared with other university students studying different fields. Additionally, it is also remarkable that the present research has shown that attitudes towards cheating did not vary according to the specific variables chosen for the present research, such as department, gender, YGS score, and the type of high school from which the students graduated, while students' attitudes varied by class years, and cheating was more common during the higher years.

\section{Recommendations}

Considering the results of this study and literature findings, the below-mentioned recommendations are made to reduce the students' level of cheating attitudes in exams.

- Students' motives for cheating can be studied; taking the advantage of the results of this study, through the exploratory sequential pattern is one of the mixed methods.

- Intrinsic and extrinsic motives for the students' cheating in exams should be identified by qualitative research methods and eliminated.

- Certain events such as panels, seminars, group discussion events on the impacts of cheating on exams should be organized for the students of teacher training programs.

- Physical arrangements of exam places should be organized to prevent cheating attempts.

\section{Acknowledgements}

The Scientific Research Projects Coordination Unit of Karabük University supported this work with Project Number: KBÜ-BAP-16/1-YD-194 


\section{REFERENCES}

[1] O'Rourke J, Barnes J, Deaton A, Fulks K, Ryan K, Rettinger DA. Imitation is the sincerest form of cheating: The influence of direct knowledge and attitudes on academic dishonesty, Ethics and Behavior, 2010; 20: 47-64.

[2] Bushway A, Nash W. School cheating behavior, Review of Education Research, 1977; 47: 623-632

[3] Aslan AK.. Social bases of the education, Balıkesir University Journal of Social Sciences, 2001; 5: 16-30.

[4] Balzer HD. 'Plans to reform Russian higher education', in Anthony Jones (ed.), Education and Society in the New Russia. Armonk, NY: M.E. Sharpe, 1994; 27.

[5] Whitley BE, Keith-Spiegel P. Academic dishonesty: An educator's guide, Mahwah, NJ: Lawrence Erlbaum Associates, 2002 .

[6] Baldwin DC, Daugherty SR, Rowley BD, Schwartz MD. Cheating in medical school: A survey of second-year students at 31 schools, Academic Medicine, 1996; 71: 267-273.

[7] Harding TS, Carpenter DD, Finelli CJ, Passow HJ. Does academic dishonesty relate to unethical behavior in professional practice? An exploratory study, Science and Engineering, 2004: 10(2); 311-324

[8] Beck L, Ajzen I. Predicting dishonest actions using the theory of planned behavior, Journal of Research in Personality, 1991; 25(3): 285-301.

[9] Fass RA. Cheating and plagiarism. In W. W. May (Ed.), Ethics In Higher Education, New York: Macmillan, 1990; 170-184.

[10] Çetin Ş. The Analysis of cheating behaviors of the college students according to different variables, Journal of National Education, 2007; 175: 129-142.

[11] Carpenter DD, Harding TS, Finelli CJ, Montgomery SM, Passow HJ. Engineering students' perceptions of and attitudes towards cheating, Journal of Engineering Education, 2006; 95(3), 181-194.

[12] Crown DF, Spiller MS. Learning from the literature on collegiate cheating: A review of empirical research, Journal of Business Ethics, 1998; 17: 683-700.

[13] Külahçı Ş, Cheating as problem in teacher training (F.Ü. Examples), II. National Education Symposium (18-20 September 1996), Istanbul: Marmara University Ataturk Education Faculty, 1996.

[14] Topcu Y, Uzundumlu AS, The students' attitude and behaviors towards cheating motivation during higher education, International Journal of Human Sciences, 2011; 8(2): 302-313.

[15] Whitley BE. Factors associated with cheating among college students: A review, Research in Higher Education, 1998; 39(3): 235-274.

[16] Wajda-Johnston VA, Handal PJ, Brawer PA, Fabricatore AN, Academic dishonesty at the graduate level, Ethics \& Behavior, 2001; 11(3): 287-305.
[17] Hinton L, Plagiarism: Learning from our challenges, Studies in Learning, Evaluation Innovation and Development, 2004; 1(1): $37-46$.

[18] Passow HJ, Mayhew MJ, Finelli CJ, Harding TS, Carpenter DD, Factors influencing engineering students' decisions to cheat by type of assessment, Research in Higher Education, 2006; 47(6): 643-684.

[19] Schab F, Schooling without learning: Thirty years of cheating in high school, Adolescence, 1991; 26: 839-847.

[20] Bowers WJ, Student dishonesty and its control in college, New York: Bureau of Applied Social Research, Columbia University, 1964.

[21] McCabe DL, Classroom cheating among natural science and engineering majors, Science and Engineering Ethics, 1997; 3: 433-445.

[22] McCabe DL, Drinan P, Toward a culture of academic integrity, Chronicle of Higher Education, 1999; 46(8): 7.

[23] Stern EB, Havlicek L. Academic misconduct: Results of faculty and undergraduate student surveys, Journal of Allied Health, 1986; 15: 129-142.

[24] Mert EL. Cheating at some department whose basic function is to train academician, International Periodical for the Language Literature and History of Turkish or Turkic. 2012; 7(3): 1813-1829.

[25] Robinson E, Amburgey R, Swank E, Faulker C, Test cheating in a rural college: Studying the importance of individual and situational factors, College Student Journal, 2004; 38: 380395.

[26] McCabe DL, Trevino LK, What we know about cheating in college: Longitudinal trends and recent developments, Change, 1996; $28: 31$.

[27] Karasar, N, Scientific Research Method (12th edition): Concepts-principles-methods. Nobel Yay, 2003,068.

[28] Semerci, Ç, The scale for attitude towards cheating, Firat University Journal of Social Science, 2003; 13(1), 227-234.

[29] Büyüköztürk, Ş, Data Analysis Handbook for Social Sciences, (19. bask1) Ankara. 2014

[30] Ünlü H, Eroğlu C, Prospective physical education teachers' attitudes towards cheating, SPORMETRE Journal of Physical Education and Sport Sciences 2012; 3: 101-106.

[31] Bozdoğan AE, Öztürk Ç, Why do teacher' candidates cheat?, Elementary Education Online, 2008; 7(1).

[32] Bjorklund M, Wenestam CG, Academic cheating: frequency, methods and causes, European Conference on Educational Research, Lahti, Finland, 22-25 September, 1999.

[33] Davis S, Ludwigson HW, Additional data on academic dishonesty and a proposal for remediation, Teaching of Psychology, 1995; 22.

[34] Diekhoff GM, LaBeff EE, Clark RE, Williams LE, Francis B, Haines VJ. College cheating: Ten years later, Research in Higher Education, 1996; 37(4): 487-502.

[35] Haines VJ, Diekhoff GM, LaBeff EE, Clark RE. College cheating: Immaturity, lack of commitment, and the neutralizing attitude, Research in Higher education, 1986; 25(4): 342-354. 
[36] Ward DA, Beck WL, Gender and dishonesty, The Journal of Social Psychology, 1990; 130(3): 333-339.

[37] Michaels J, Miethe T, Applying theories of deviance to academic cheating. Social Science Quarterly, 1989; 70: 87.

[38] Davis S, Grover C, Becker A, McGregor L, Academic dishonesty: Prevalence, determinants, techniques, and a proposal for remediation. Teaching of Psychology, 1992; 19: 1.

[39] Akdağ M, Güneş H, Cheating behaviors and attitudes toward cheating. Educational Administration Theory and Practice 2002; 8(3): 330-343.

[40] Yangın S, Kahyaoğlu M, Attitudes and ideas of candidate primary school teachers towards copying. Balıkesir Üniversitesi Balıkesir University Journal of Social Sciences Institute 2009; 12(21): 46-55.

[41] Lin CHS, Wen LYM, Academic dishonesty in higher education: A nationwide study in Taiwan, Higher Education, 2007; 54(1): 85-97.

i This paper was orally presented at the 4th International Symposium on New Issues in Teacher Education (ISNITE) at Savolinna University, Finland.
[42] Hardigan PC. First and third year pharmacy students' attitudes toward cheating behaviors. American Journal of Pharmaceutical Education, 2004; 68 (5).

[43] Ellenburg FC, Cheating on tests, The Clearing House: A Journal of Educational Strategies, Issues and Ideas, 1973; 47(7): 427-430.

[44] DeVries DL, Ajzen I, The relationship of attitudes and normative beliefs to cheating in college, The Journal of Social Psychology, 1971; 83(2): 199-207.

[45] Franklyn-Stokes A, Newstead SE, Undergraduate cheating: who does what and why?, Studies in higher education, 1995; 20(2): 159-172.

[46] Newstead, SE; Franklyn-stokes, Arlene; Armstead, P, Individual differences in student cheating. Journal of Educational Psychology, 1996, 88.2: 229. 